\title{
High-temperature thermomagnetic properties of vivianite nodules, Lake El'gygytgyn, Northeast Russia
}

\author{
P. S. Minyuk ${ }^{1}$, T. V. Subbotnikova ${ }^{1}$, L. L. Brown ${ }^{2}$, and K. J. Murdock ${ }^{2}$ \\ ${ }^{1}$ North-East Interdisciplinary Scientific Research Institute, Far East Branch of the Russian Academy of Sciences, \\ Magadan, Russia \\ ${ }^{2}$ Department of Geosciences, University of Massachusetts, Amherst, USA
}

Correspondence to: P. S. Minyuk (minyuk@neisri.ru)

Received: 7 September 2012 - Published in Clim. Past Discuss.: 9 October 2012

Revised: 15 January 2013 - Accepted: 15 January 2013 - Published: 19 February 2013

\begin{abstract}
Vivianite, a hydrated iron phosphate, is abundant in sediments of Lake El'gygytgyn, located in the Anadyr Mountains of central Chukotka, northeastern Russia $\left(67^{\circ} 30^{\prime} \mathrm{N}, 172^{\circ} 05^{\prime} \mathrm{E}\right)$. Magnetic measurements, including mass-specific low-field AC magnetic susceptibility, fielddependent magnetic susceptibility, hysteresis parameters, temperature dependence of the induced magnetization, as well as susceptibility in different heating media, provide ample information on vivianite nodules. Electron microprobe analyses, electron microscopy and energy dispersive spectroscopy were used to identify diagnostic minerals. Vivianite nodules are abundant in both sediments of cold (anoxic) and warm (oxic) stages. Magnetic susceptibility of the nodules varies from $0.78 \times 10^{-6} \mathrm{~m}^{3} \mathrm{~kg}^{-1}$ to $1.72 \times 10^{-6} \mathrm{~m}^{3} \mathrm{~kg}^{-1}$ (average $=1.05 \times 10^{-6} \mathrm{~m}^{3} \mathrm{~kg}^{-1}$ ) and is higher than the susceptibility of sediments from the cold intervals. Magnetic properties of vivianite are due to the respective product of oxidation as well as sediment and mineral inclusions. Three types of curves for high-temperature dependent susceptibility of vivianite indicate different degrees of oxidation and inclusions in the nodules. Vivianite acts as a reductant and reduces hematite to magnetite and masks the goethite-hematite transition during heating. Heating vivianite and sulfur mixtures stimulates the formation of monoclinic pyrrhotite. An additive of arsenic inhibits the formation of magnetite prior to its Curie temperature. Heating selective vivianite and pyrite mixtures leads to formation of several different minerals magnetite, monoclinic pyrrhotite, and hexagonal pyrrhotite, and makes it difficult to interpret the thermomagnetic curves.
\end{abstract}

\section{Introduction}

Vivianite, $\mathrm{Fe}_{3}\left(\mathrm{PO}_{4}\right)_{2} 8 \mathrm{H}_{2} \mathrm{O}$, is a hydrated iron phosphate that has long been identified in a variety of natural environments. This authigenic mineral forms when anoxic environments provide readily available ferrous iron - usually dissolution products of iron oxides, desorption of iron-bearing silicates, and inorganic phosphorus. It has been found as a secondary mineral in a wide range of situations including weathering products of hydrothermal deposits, Fe-bearing ore veins, reducing soils and aquifers, and lacustrine and marine reduced sediments. The presence of vivianite in lake sediments is well documented, and it has been the subject of detailed studies in many lacustrine environments from large lakes such as Lake Baikal (Fagel et al., 2005; Sapota et al., 2006), to small mesotrophic lakes in the Canadian prairie (Manning et al., 1991, 1999) to Holocene muds in Norway (Rosenquist, 1970) to Lago Maggiore, Italy (Nembrin et al., 1983). The formation of authigenic vivianite in lake sediments is not fully understood, but appears to be influenced by redox conditions, $\mathrm{pH}$ values, dissolved elements - primarily $\mathrm{Fe}$ and $\mathrm{P}$, but often including impurities of $\mathrm{Ca}, \mathrm{Mn}$, and $\mathrm{Mg}-$ organic matter content, and sedimentation rate (Sapota et al., 2006). Vivianite is usually a stable mineral in environments over the $\mathrm{pH}$ range of 6 to 9 and low Eh values of less than 0.0 (Nriagu and Dell, 1974). Vivianite is found as small disaggregate crystals to large nodules, often several centimeters in diameter. In air vivianite readily oxidizes, turning from opaque or white to vivid blue in a short time, eventually altering to metavivianite (kerchenite) (Rodgers, 1986) or santabarbaraite (Pratesi et al., 2003), as the original $\mathrm{Fe}^{+2}$ becomes 
completely replaced by $\mathrm{Fe}^{+3}$. The magnetic properties of vivianite are well known (Meijer et al., 1967), and although it is paramagnetic in natural environments and surface temperature, it becomes antiferromagnetic at exceedingly low temperature with a Néel temperature of $\sim 12 \mathrm{~K}$ (Meijer et al., 1967; Frederichs et al., 2003). Maximum magnetic susceptibility (MS) of vivianite $\left(6.62 \times 10^{-6} \mathrm{~m}^{3} \mathrm{~kg}^{-1}\right)$ is observed at the Néel temperature (Frederichs et al., 2003). In this paper we investigate the magnetic properties, especially those at high temperature (up to $700{ }^{\circ} \mathrm{C}$ ), of vivianite nodules found in the sediments of Lake El'gygytgyn in northeastern Siberia. Magnetic behavior of vivianite particles and nodules is important to the overall interpretation of magnetic properties of lacustrine sediments that are used as environmental proxies. At room temperature the susceptibility of El'gygytgyn Lake nodules is close to $1 \times 10^{-6} \mathrm{~m}^{3} \mathrm{~kg}^{-1}$; this is higher than MS of cold stage sediment, but lower than MS of warm stage sediment. Sediment of high and low magnetic parameters shows different curves of temperature dependence magnetic susceptibility. Cooling curves plot above heating curves for samples from cold climate intervals, indicating formation of new higher susceptibility phases possibly as the result of vivianite alteration.

Although vivianite is paramagnetic at room temperature, studies of nodules of the material investigate the presence or absence of magnetic grains within the vivianite and oxidation, and shed light on the magnetic properties of lake sediments where vivianite is common.

\section{Geologic setting}

Vivianite was studied from sediments of Lake El'gygytgyn, located in the Anadyr Mountains of central Chukotka, northeastern Russia $\left(67^{\circ} 30^{\prime} \mathrm{N}, 172^{\circ} 05^{\prime} \mathrm{E}\right)$ (Fig. 1). The lake is situated in a 3.6 Ma impact crater located in a series of volcanic rocks (rhyodacite ignimbrites, rhyolite to andesite tuffs, and basalt flows) of the late Cretaceous age (Bely and Belaya, 1998; Bely and Raikevich, 1994; Gurov et al., 2007; Layer, 2000). Sediment input to the lake is controlled by a series of some 50 small inlet streams draining the crater; output from the lake is only by one stream, the Enmyvaam River, flowing southeast from the crater to the Bering Sea (Nolan and Brigham-Grette, 2007). Preliminary studies and short cores collected from the lake (Brigham-Grette et al., 2007) attested to the suitability of lake El'gygytgyn sediments to provide a detailed climate record for this high arctic site. Additional deep drilling was done in 2008-2009, when over $318 \mathrm{~m}$ of sediment core and $200 \mathrm{~m}$ of impact breccia was extracted by ICDP at site 5011 in the lake (Melles et al., 2011), providing a vast amount of material to be studied for paleoclimate information (Melles et al., 2012, and papers within this issue). Geomorphological data indicate that the crater has never been glaciated (Glushkova, 2001) and no hiatus in sedimentation is observed (Melles et al., 2011).
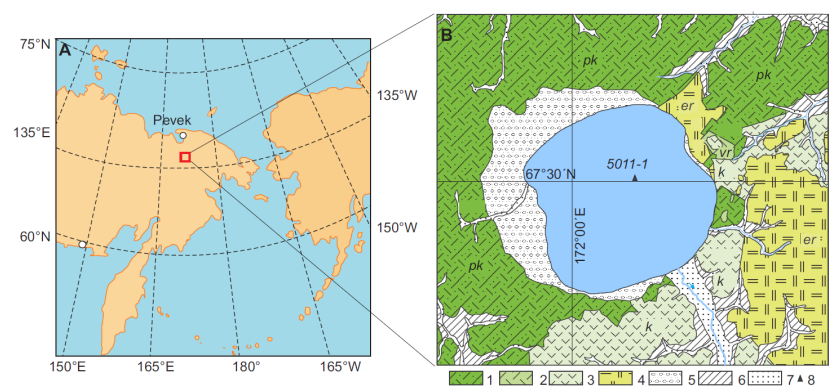

Fig. 1. (A) Location of Lake El'gygytgyn in easternmost Russia. (B) Simplified bedrock geologic map of the Lake El'gygytgyn adapted from Bely and Raikevich (1994); Bely and Belaya (1998). Formation: 1 - Pykarvaam (pk); 2 - Voronian (vr); 3 - Koekvun' (k); 4 - Ergyvaam (er); 5 - deluvian; 6 - terrace deposits; 7 - flood plain deposits; 8 - core site.

Chronology of the entire package has been established using a paleomagnetic timescale with detailed tuning to the marine oxygen isotope record and insolation variations (Melles et al., 2012; Nowaczyk et al., 2013). Biological, physical and chemical proxies reflect glacial/interglacial climatic conditions (Melles et al., 2012). During cold climatic stages conditions included perennial lake ice, oxygen-depleted bottom waters, absence of bioturbation and enhanced preservation of organic matter (Melles et al., 2007), resulting in the dissolution of magnetic minerals (Nowaczyk et al., 2002). A perennial ice cover on the lake obviously restricted the transport of coarse-grained sediments but enabled finer particles to be transported to central part of the lake basin through cracks or moats around the shore during summer (Asikainen et al., 2007).

Sediments from cold climate stages are enriched in $\mathrm{Al}_{2} \mathrm{O}_{3}$, $\mathrm{MgO}, \mathrm{TiO}_{2}, \mathrm{Fe}_{2} \mathrm{O}_{3}, \mathrm{Ni}, \mathrm{Cr}$, and have high MS (Minyuk et al., 2007, 2013). During warm climate periods conditions include seasonal ice cover, decomposition of organic matter in bottom waters, oxic conditions, high level of bioturbation, low dissolution of magnetic minerals, and input of less chemical altered material. The resulting sediment is characterized by high content of $\mathrm{CaO}, \mathrm{Na}_{2} \mathrm{O}, \mathrm{SiO}_{2}, \mathrm{~K}_{2} \mathrm{O}, \mathrm{Sr}$, and low values of organic carbon, sulfur, and nitrogen.

Vivianite has been identified extensively in the earlier, shorter cores (Asikainen et al., 2007; Minyuk et al., 2007) using both observational and laboratory techniques, and interpreted as forming under anoxic conditions when phosphorus and iron were both plentiful. Fine-grained dispersed vivianite has been recognized using low-temperature magnetic measurements down to $10 \mathrm{~K}$ (Murdock et al., 2012). Due to the ubiquitous occurrence of vivianite in cold (anoxic) and warm (oxic) stage sediments, Minyuk et al. (2007) conclude that its formation is controlled by diagenetic microenvironments and not influenced by large-scale climate conditions. 


\section{Materials and method}

Vivianite nodules and pieces were collected down continuous core (Core 1A, 1B of ICDP site 5011) from 5.67 to $28 \mathrm{~m}$ in composite depth with ages 125.1-682.5 kyr (Melles et al., 2012).

Both sediment and nodules were retained for study, with the nodules separated from lake sediment by sieving, using a $250 \mu \mathrm{m}$ sieve. The nodules were analyzed using a range of thermomagnetic and mineralogical methods at the North-East Interdisciplinary Scientific Research Institute of the Far East Branch of the Russian Academy of Sciences. Mass-specific low-field AC MS, as well as field-dependent and frequency-dependent MS were measured on a MFK1FA Kappabridge (AGICO Ltd., Brno, Czech Republic) with sensitivity $3 \times 10^{-8} \mathrm{SI}$. Hysteresis parameters, including saturation magnetization $\left(J_{\mathrm{s}}\right)$, induced magnetization $\left(J_{\mathrm{i}}\right)$, saturation remanence $\left(J_{\mathrm{rs}}\right)$, coercive force $\left(B_{\mathrm{c}}\right)$, and remanence coercivity $\left(B_{\mathrm{cr}}\right)$ were measured by an automatic coercive spectrometer (Burov et al., 1986). Sensitivity of magnetic moment $J_{\mathrm{rs}}$ is $1 \times 10^{-8} \mathrm{Am}^{2}$, sensitivity of magnetic moment $J_{\mathrm{i}}$ is $1 \times 10^{-6} \mathrm{Am}^{2}$, and maximum specimen volume is $1.92 \mathrm{~cm}^{3}$.

The temperature dependence of the induced magnetization $\left(J_{\mathrm{i}}-T\right)$ was measured on a Curie express balance (Burov et al., 1986) in field of $500 \mathrm{mT}$ with heating rate of $100^{\circ} \mathrm{min}^{-1}$ and sensitivity of magnetic moment $J_{\mathrm{i}} 3 \times 10^{-8} \mathrm{Am}^{2}$, and maximum specimen volume $0.07 \mathrm{~cm}^{3}$. Two heating runs were used. Temperature-dependent susceptibility (K-T) of crushed nodules was measured continuously from room temperature up to $700^{\circ} \mathrm{C}$ and back to room temperature using a MFK1-FA Kappabridge equipped with a CS-3 hightemperature furnace (AGICO Ltd., Brno, Czech Republic) with sensitivity $1 \times 10^{-7} \mathrm{SI}$ and maximum specimen volume $0.25 \mathrm{~cm}^{3}$. The heating and cooling rates were 10 $12^{\circ} \mathrm{C} \mathrm{min}^{-1}$. Software CUREVAL ver.8.0.1. (http://www. agico.com/) was used for resolution of susceptibility into ferromagnetic and paramagnetic components based on CurieWeiss law (Hrouda, 1994) and for Curie temperatures estimation using the two-tangent method (Petrovský and Kapička, 2006).

Crushed vivianite nodules were heated in air. Powders from several vivianite nodules were mixed with sucrose (organic carbon), carbamide (nitrogen compound $\left(\mathrm{NH}_{2}\right)_{2} \mathrm{CO}$ ), metallic powders of arsenic, and elemental sulfur, with the additives never being more then $5 \%$ of the total material. Samples were then heated continuously from room temperature to $700^{\circ} \mathrm{C}$ and cooled back to room temperature. Additives were used to simulate some chemical conditions in bottom sediments. Melles et al. (2007) show that El'gygytgyn Lake sediment, accumulated during cold climates, is enriched in total organic carbon, total sulfur, and total nitrogen. We found framboidal pyrite and fine-grained greigite in the sediment. Some sulfide grains included in vivianite nodules and as heating products of decomposition of pyrite and
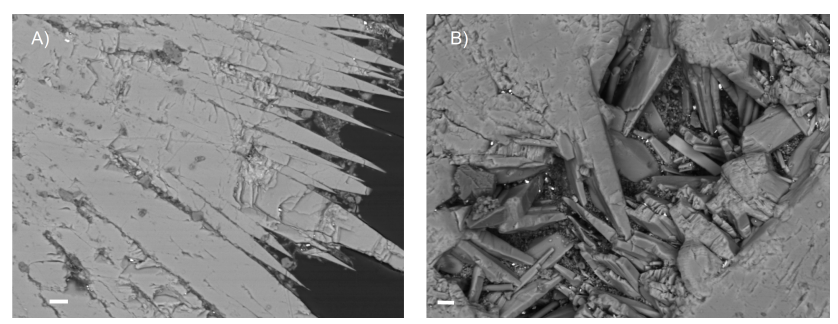

Fig. 2. Backscattered electron images of polished sections of vivianite microconcretions: (A) outer surface of a concretion, (B) inner part of a concretion with visible crystals. Scale (white line) is $20 \mu \mathrm{m}$.

greigite can affect the high-temperature property of vivianite. Chalcopyrite (FeAsS) and impurity of arsenic in some pyrite framboids were determined by energy dispersive spectroscopy. Although arsenic was not found in El'gygytgyn vivianite nodules it could potentially be adsorbed onto vivianite (Thinnappan et al., 2008). To study the effect of vivianite on other minerals during heating, selected vivianite samples were heated with hematite and goethite: both of which were also detected in the sediments.

Electron microprobe (EMP) analyses of polished nodules mounted in epoxy resin were performed using "Camebax" microprobe (manufactured by Cameca Instruments in France) under an accelerating voltage of $25 \mathrm{kV}$ and electronbeam spot size of $4 \mu \mathrm{m}$. Crystal LIF for $\mathrm{FeK}_{\alpha}$ and $\mathrm{MnK}_{\alpha}$ lines, and crystal PET for $\mathrm{PK}_{\alpha}$ lines were used. The standards used were hematite $(\mathrm{Fe})$, apatite $(\mathrm{P})$ and $\mathrm{MnTiO}_{3}(\mathrm{Mn})$. Specimens for scanning electron microscopy (SEM) and energy dispersive spectroscopy (EDS) analyses were mounted on aluminum stubs and carbon coated. The SEM-EDS analyses have been carried out using QEMSCAN system including scanning electron microscopy (EVO-50) with energy dispersive X-ray spectroscopy Quantax Esprit (Bruker, Germany).

The chemical composition and major elements in the lake sediments minus the large $(>250 \mu \mathrm{m})$ nodules were analyzed using a multichannel X-ray fluorescence (XRF) spectrometer SRM-25 (former USSR) and S4 Pioneer X-ray fluorescence spectrometer (Bruker, Germany). Elemental compositions were determined using the fundamental parameters method (Borkhodoev, 2002).

\section{Results}

Vivianite nodules range in size up to $3 \mathrm{~cm}$. They are composed of crystal aggregates often having spherical morphology, sometimes crystal clusters or flat crusts. Surfaces of nodules are darker than inner parts, with a striking bluish to greenish color appearing on the surface with oxidation. Many spherical nodules are empty in the central parts or consist of visible crystals clusters; morphologies of inner and outer parts of typical nodules are illustrated in Fig. 2. 


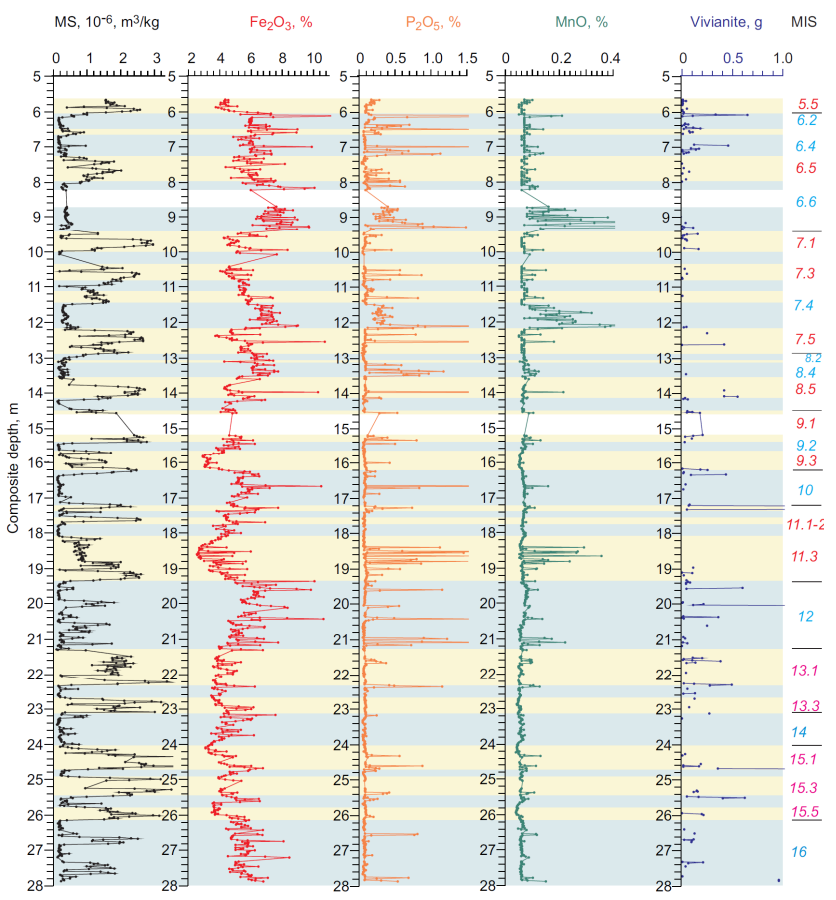

Fig. 3. Distribution of magnetic susceptibility (MS), percent of $\mathrm{Fe}_{2} \mathrm{O}_{3}, \mathrm{P}_{2} \mathrm{O}_{5}$, and $\mathrm{MnO}$, and occurrence of vivianite nodules, in grams, in sediment samples over $28 \mathrm{~m}$ of core material. Marine isotope stages (MIS) adapted from Bassinot et al. (1994). Blue (yellow) bars indicate cold (warm) stages.

\subsection{Microprobe analyses - nodules and sediments}

Electron microprobe quantitative analyses of 10 selected nodules reveal the presence of $\mathrm{Fe}_{2} \mathrm{O}_{3}, \mathrm{P}_{2} \mathrm{O}_{5}$ and $\mathrm{MnO}$. The average content of $\mathrm{Fe}_{2} \mathrm{O}_{3}$ is $35.18 \%$, with a range from 30.18 to $39.4 \%$. $\mathrm{P}_{2} \mathrm{O}_{5}$ displays values between $21.23-29.28 \%$ (average $25.02 \%$ ) with $\mathrm{MnO}$ concentration varying from 0.67 to $6.34 \%$ (average $2.06 \%$ ) (Table 1). The ratio of phosphorus to manganese in the vivianite samples range from 4.61 to 37.45 .

This composition is very close to the composition of vivianite nodules from lacustrine sediment in Greece (Stamatakis and Koukouzas, 2001): $\mathrm{Fe}_{2} \mathrm{O}_{3}$ is (36.67-38.04\%), $\mathrm{MnO}$ is $(2.53-2.66 \%), \mathrm{P}_{2} \mathrm{O}_{5}$ is $(21.92-24.81 \%)$. On the other hand, nodules from Baikal Lake sediment are enriched in $\mathrm{MnO}$ but depleted in $\mathrm{P}_{2} \mathrm{O}_{5}$ (Fagel et al., 2005; Sapota et al., 2006). Except for $\mathrm{MnO}$, trace $\mathrm{Mg}$ and $\mathrm{Zn}$ were detected in vivianite nodules from Bolivia (Rodgers et al., 1993).

Major elements determination was performed on sediment samples from which large $(>250 \mu \mathrm{m})$ vivianite nodules were removed (Minyuk et al., 2007, 2013). Figure 3 shows the distribution of $\mathrm{Fe}_{2} \mathrm{O}_{3}, \mathrm{P}_{2} \mathrm{O}_{5}$, and $\mathrm{MnO}$ along the depth profile. Distribution of both $\mathrm{P}_{2} \mathrm{O}_{5}$ and $\mathrm{MnO}$ are synchronous in this section, whereas $\mathrm{Fe}_{2} \mathrm{O}_{3}$ appears to vary independent of $\mathrm{P}_{2} \mathrm{O}_{5}$ and $\mathrm{MnO}$, with some intervals showing strong correlations, but other regions where low $\mathrm{Fe}_{2} \mathrm{O}_{3}$ content corresponds to

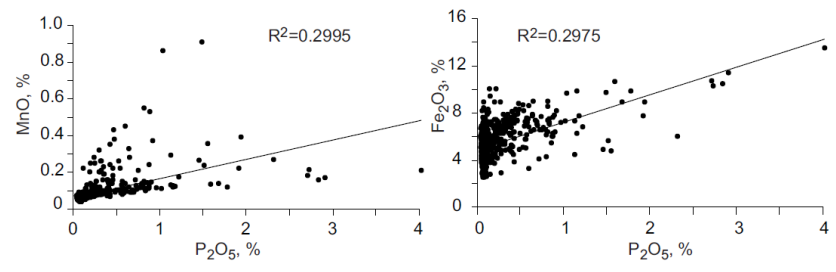

Fig. 4. Scatter plots of $\mathrm{P}_{2} \mathrm{O}_{5}$ versus $\mathrm{MnO}$, and $\mathrm{P}_{2} \mathrm{O}_{5}$ versus $\mathrm{Fe}_{2} \mathrm{O}_{3}$ concentrations for sediment.

the phosphorus and manganese highs. For all samples the correlation coefficient (Pearson) between $\mathrm{P}_{2} \mathrm{O}_{5}$ and $\mathrm{MnO}$ is 0.55; between $\mathrm{Fe}_{2} \mathrm{O}_{3}$ and $\mathrm{P}_{2} \mathrm{O}_{5}$ it is 0.55 (Fig. 4).

Distribution of phosphorus and manganese shows few levels with higher concentrations of these elements - depth intervals 8.71-9.21, 11.51-12.19, 13.19-13.51, 18.39-18.85, 20.95-21.17, 24.31-24.73 m (Fig. 3, Table 2). Geochemical data suggest that fine-grained vivianite minerals are present at these levels. Smear slides prepared from sediments in the indicated regions reveal blue, greenish vivianite aggregates and broken pieces of fine concretions. A maximum amount of the oxides in the studied interval are $\mathrm{Fe}_{2} \mathrm{O}_{3}$ is $13.54 \%$, $\mathrm{P}_{2} \mathrm{O}_{5}$ is $4.02 \%, \mathrm{MnO}$ is $0.91 \%$. The phosphate mineral apatite is not responsible for phosphorus spikes because of the absence of correlation between phosphorus and calcium, which are the main elements of apatite.

\subsection{Scanning electron microscopy and energy dispersive spectroscopy}

In most cases, the vivianite concretions studied are not homogeneous, but contain irregular oxidized patches as well as discrete mineral inclusions. Ten polished nodules were studied by electron microscopy (SEM) and energy dispersive spectroscopy (EDS). Backscatter images with accompanying EDS elemental scans are shown in Fig. 5. As can be observed in Fig. 5a and b, the lighter colored parts of the backscattered electron images have higher contents of Fe and P. Some of the studied vivianite nodules were attracted to a hand magnet. A few of these "magnetic" nodules were crushed and the resulting magnetic extract was studied using SEM and EDS. In a few grains sulfides of Fe, presumably greigite, were found (Fig. 5c), identified by the presence of iron and sulfur, and the absence of phosphorus. A semiquantitative composition of sulfide is $\mathrm{Fe}=46.20-50.23$ norm. wt $\%, \mathrm{~S}=35.62-33.26$ norm. wt $\%, \mathrm{Ni}=2.31-2.77$ norm. wt $\%$, and a few percent of $\mathrm{Mg}, \mathrm{Al}, \mathrm{K}$, and $\mathrm{Si}$. In some nodules ilmenite was identified (Fig. 5d) by the combined presence of iron and titanium, with a composition of $\mathrm{Fe}=38.30-42.58, \mathrm{Ti}=29.31-34.86$, $\mathrm{O}=21.93-28.54, \mathrm{Al}$ and $\mathrm{Si}<1 \%$. Although rare, in a few samples Fe-rich phases were found, with iron $(\mathrm{Fe}=82.87$ 92.90 norm. wt \%) the main constituent and only a few percent $\mathrm{P}, \mathrm{Mn}$, and $\mathrm{Si}$. All the nodules investigated were found to include minor minerals with high contents of $\mathrm{Si}, \mathrm{Al}$, and $\mathrm{Na}$. 
Table 1. Electron microprobe analyses of selected vivianite nodules from Lake El'gygytgyn.

\begin{tabular}{|c|c|c|c|c|c|c|c|c|c|c|c|}
\hline Nodule & Analysis & $\mathrm{P}_{2} \mathrm{O}_{5}, \%$ & $\mathrm{Fe}_{2} \mathrm{O}_{3}, \%$ & $\mathrm{MnO}, \%$ & $\mathrm{P}, \%$ & $\mathrm{Fe}, \%$ & $\mathrm{Mn}, \%$ & $\mathrm{P}$ & $\mathrm{Fe}$ & $\mathrm{Mn}$ & $\mathrm{P} / \mathrm{Mn}$ \\
\hline & & & & & & & & \multicolumn{3}{|c|}{ normalized wt $\%$} & wt/wt \\
\hline \multirow{4}{*}{10} & 1 & 27.61 & 39.4 & 1.85 & 12.06 & 30.54 & 1.43 & 40.46 & 56.83 & 2.71 & 14.93 \\
\hline & 2 & 21.23 & 34.01 & 2.22 & 9.27 & 26.36 & 1.72 & 37.29 & 58.81 & 3.90 & 9.56 \\
\hline & 3 & 27.80 & 37.64 & 2.01 & 12.14 & 29.18 & 1.56 & 41.58 & 55.42 & 3.01 & 13.81 \\
\hline & 4 & 25.37 & 37.57 & 1.33 & 11.08 & 29.12 & 1.03 & 39.84 & 58.07 & 2.09 & 19.06 \\
\hline \multirow{4}{*}{9} & 5 & 26.39 & 37.37 & 1.22 & 11.52 & 28.97 & 0.95 & 40.98 & 57.12 & 1.90 & 21.57 \\
\hline & 6 & 25.07 & 39.24 & 0.67 & 10.95 & 30.42 & 0.52 & 38.95 & 60.01 & 1.04 & 37.45 \\
\hline & 7 & 22.07 & 37.18 & 1.02 & 9.64 & 28.82 & 0.79 & 36.97 & 61.32 & 1.71 & 21.62 \\
\hline & 8 & 25.78 & 35.96 & 1.46 & 11.26 & 27.88 & 1.13 & 41.16 & 56.51 & 2.33 & 17.67 \\
\hline \multirow{2}{*}{8} & 9 & 25.95 & 33.99 & 4.31 & 11.33 & 26.35 & 3.34 & 40.72 & 52.51 & 6.77 & 6.01 \\
\hline & 12 & 29.28 & 34.03 & 6.34 & 12.79 & 26.38 & 4.91 & 42.36 & 48.46 & 9.18 & 4.61 \\
\hline \multirow{4}{*}{7} & 13 & 26.46 & 36.11 & 1.92 & 11.55 & 27.99 & 1.49 & 41.39 & 55.60 & 3.00 & 13.80 \\
\hline & 14 & 27.91 & 36.18 & 1.31 & 12.19 & 28.05 & 1.02 & 43.05 & 54.93 & 2.02 & 21.31 \\
\hline & 15 & 23.08 & 31.74 & 2.15 & 10.08 & 24.60 & 1.67 & 40.87 & 55.32 & 3.81 & 10.73 \\
\hline & 16 & 25.49 & 36.88 & 1.93 & 11.13 & 28.59 & 1.50 & 40.00 & 56.97 & 3.03 & 13.20 \\
\hline \multirow{4}{*}{6} & 17 & 22.7 & 34.61 & 1.62 & 9.91 & 26.83 & 1.26 & 38.88 & 58.35 & 2.78 & 13.99 \\
\hline & 18 & 25.64 & 38.16 & 1.38 & 11.20 & 29.58 & 1.07 & 39.70 & 58.16 & 2.14 & 18.55 \\
\hline & 19 & 26.93 & 36.44 & 1.11 & 11.76 & 28.25 & 0.86 & 42.14 & 56.13 & 1.74 & 24.22 \\
\hline & 20 & 25.76 & 35.44 & 1.88 & 11.25 & 27.47 & 1.46 & 41.20 & 55.79 & 3.01 & 13.69 \\
\hline \multirow{4}{*}{5} & 21 & 26.21 & 36.43 & 2.22 & 11.45 & 28.24 & 1.72 & 40.77 & 55.78 & 3.45 & 11.82 \\
\hline & 22 & 25.27 & 35.43 & 1.84 & 11.03 & 27.47 & 1.43 & 40.77 & 56.26 & 2.97 & 13.73 \\
\hline & 23 & 24.72 & 35.48 & 2.07 & 10.79 & 27.50 & 1.60 & 40.05 & 56.59 & 3.36 & 11.92 \\
\hline & 24 & 26.41 & 33.83 & 4.36 & 11.53 & 26.22 & 3.38 & 41.22 & 51.97 & 6.81 & 6.05 \\
\hline \multirow{4}{*}{4} & 25 & 25.58 & 36.00 & 3.61 & 11.17 & 27.91 & 2.80 & 39.58 & 54.83 & 5.59 & 7.08 \\
\hline & 26 & 25.99 & 34.15 & 1.35 & 11.35 & 26.47 & 1.05 & 42.64 & 55.15 & 2.22 & 19.21 \\
\hline & 27 & 23.48 & 34.61 & 2.20 & 10.25 & 26.83 & 1.71 & 39.30 & 57.02 & 3.68 & 10.68 \\
\hline & 28 & 24.85 & 34.14 & 2.21 & 10.85 & 26.47 & 1.71 & 40.96 & 55.39 & 3.65 & 11.22 \\
\hline \multirow{4}{*}{3} & 29 & 22.52 & 32.41 & 1.67 & 9.834 & 25.12 & 1.29 & 40.15 & 56.87 & 2.98 & 13.47 \\
\hline & 30 & 22.83 & 34.13 & 1.23 & 9.969 & 26.46 & 0.95 & 39.60 & 58.27 & 2.13 & 18.59 \\
\hline & 31 & 22.60 & 30.18 & 1.36 & 9.869 & 23.40 & 1.05 & 42.11 & 55.35 & 2.54 & 16.58 \\
\hline & 32 & 22.16 & 32.10 & 2.55 & 9.677 & 24.88 & 1.98 & 39.35 & 56.12 & 4.53 & 8.69 \\
\hline \multirow{4}{*}{2} & 33 & 22.43 & 32.87 & 2.15 & 9.795 & 25.48 & 1.67 & 39.39 & 56.83 & 3.78 & 10.42 \\
\hline & 34 & 25.54 & 35.07 & 1.72 & 11.15 & 27.19 & 1.33 & 41.34 & 55.88 & 2.79 & 14.82 \\
\hline & 35 & 23.26 & 34.33 & 2.71 & 10.16 & 26.61 & 2.10 & 38.92 & 56.54 & 4.54 & 8.57 \\
\hline & 36 & 25.98 & 34.59 & 1.89 & 11.34 & 26.81 & 1.47 & 41.96 & 54.99 & 3.05 & 13.76 \\
\hline \multirow{3}{*}{1} & 37 & 24.79 & 34.34 & 1.32 & 10.83 & 26.62 & 1.02 & 41.38 & 56.42 & 2.20 & 18.81 \\
\hline & 38 & 25.52 & 34.28 & 1.58 & 11.14 & 26.57 & 1.22 & 41.94 & 55.46 & 2.60 & 16.13 \\
\hline & 39 & 25.22 & 35.52 & 2.45 & 11.01 & 27.53 & 1.90 & 40.26 & 55.82 & 3.91 & 10.30 \\
\hline
\end{tabular}

On the electron images these minerals look like dark patches and show up as several different forms and sizes.

\subsection{Magnetic susceptibility of vivianite nodules}

Nodules were found in sediments with both high and low MS (Fig. 3, Table 3). In general, MS of the sediment section studied here varies from $0.09 \times 10^{-6} \mathrm{~m}^{3} \mathrm{~kg}^{-1}$ to $5.12 \times 10^{-6} \mathrm{~m}^{3} \mathrm{~kg}^{-1}$ (average $0.95 \times 10^{-6} \mathrm{~m}^{3} \mathrm{~kg}^{-1}$ ).
MS of nodules $(n=54)$ shows values between $0.78 \times 10^{-6} \mathrm{~m}^{3} \mathrm{~kg}^{-1}$ and $1.72 \times 10^{-6} \mathrm{~m}^{3} \mathrm{~kg}^{1-}$ (average $\left.=1.05 \times 10^{-6} \mathrm{~m}^{3} \mathrm{~kg}^{-1}\right)$. These values are much higher than those from the intervals of low MS in core sediments.

MS of bulk sediments from low-magnetic intervals ranges from $0.09 \times 10^{-6} \mathrm{~m}^{3} \mathrm{~kg}^{-1}$ to $1.73 \times 10^{-6} \mathrm{~m}^{3} \mathrm{~kg}^{-1}$ (average $\left.0.39 \times 10^{-6} \mathrm{~m}^{3} \mathrm{~kg}^{-1}\right), n=583$. From the highmagnetic intervals, the MS of bulk sediments varies between $0.18 \times 10^{-6} \mathrm{~m}^{3} \mathrm{~kg}^{-1}$ and $5.12 \times 10^{-6} \mathrm{~m}^{3} \mathrm{~kg}^{-1}$ (average 
Table 2. Chemical composition of P-Mn rich sediments intervals.

\begin{tabular}{rrrrrr}
\hline Depth, $\mathrm{m}$ & $\mathrm{Fe}_{2} \mathrm{O}_{3}, \%$ (average) & $\mathrm{P}_{2} \mathrm{O}_{5}, \%$ (average) & $\mathrm{MnO}, \%$ (average) & $\mathrm{Mn} / \mathrm{P}$ & $\mathrm{Fe} / \mathrm{P}$ \\
\hline $8.71-9.21$ & $6.33-8.97(7.58)$ & $0.20-0.88(0.44)$ & $0.08-0.45(0.19)$ & 0.43 & 17.22 \\
$11.51-12.19$ & $5.61-8.99(7.03)$ & $0.12-1.94(0.39)$ & $0.07-0.55(0.20)$ & 0.51 & 18.71 \\
$13.19-13.51$ & $6.03-7.74(6.72)$ & $0.09-1.18(0.46)$ & $0.07-0.12(0.09)$ & 0.20 & 14.60 \\
$18.39-18.85$ & $2.54-5.99(3.57)$ & $0.06-2.32(0.52)$ & $0.05-0.36(0.12)$ & 0.23 & 6.86 \\
$20.95-21.17$ & $4.48-7.74(5.67)$ & $0.06-1.92(0.53)$ & $0.05-0.22(0.10)$ & 0.19 & 10.69 \\
$24.31-24.73$ & $3.96-6.77(5.17)$ & $0.07-0.88(0.21)$ & $0.05-0.13(0.07)$ & 0.33 & 24.61 \\
\hline
\end{tabular}
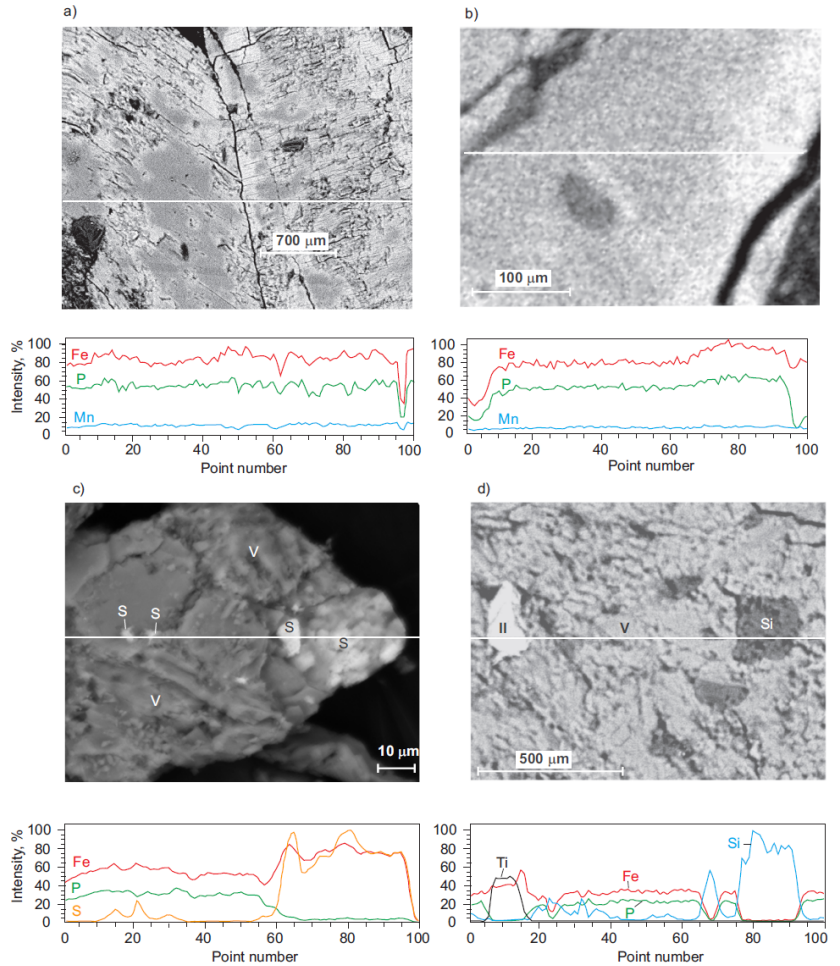

Fig. 5. Backscattered electron images of polished sections of vivianite nodules and energy dispersive spectroscopy. V - vivianite, $\mathrm{S}$ - sulfides, Il - ilmenite, $\mathrm{Si}$ - siliclastic.

$\left.1.8 \times 10^{-6} \mathrm{~m}^{3} \mathrm{~kg}^{-1}\right), n=374$. As plotted in Fig. 6 , there can be observed a positive correlation between magnetic susceptibilities of the nodules and the sediments from which they were extracted. It should be noted that the vivianite nodules never yield susceptibility below $0.8 \times 10^{-6} \mathrm{~m}^{3} \mathrm{~kg}^{-1}$, although the sediments can have much lower susceptibilities. Over half of the nodules measured come from sediment with low $\left(<1.0 \times 10^{-6} \mathrm{~m}^{3} \mathrm{~kg}^{-1}\right)$ susceptibility.

Selected nodule samples, all from zones of low susceptibility, were measured for susceptibility in a range of magnetic fields from 5 to $700 \mathrm{~A} \mathrm{~m}^{-1}$. There is considerable scatter in the measurements at low fields $\left(<100 \mathrm{~A} \mathrm{~m}^{-1}\right)$, probably due to relatively high measuring error at very low fields (Hrouda et al., 2006) when dealing with paramagnetic material. Above $100 \mathrm{~A} \mathrm{~m}^{-1}$ samples show very little change in

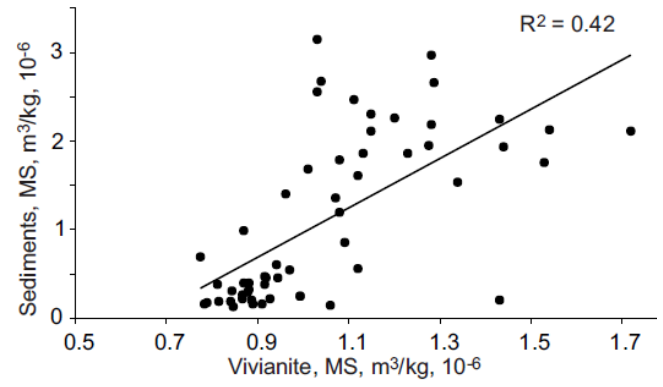

Fig. 6. Magnetic susceptibility of sediments versus magnetic susceptibility of vivianite nodules.

susceptibility - less than a few percent - whereas one sample shows a consistent susceptibility but some $10 \%$ higher than the original value.

\subsection{High-temperature dependence of magnetic susceptibility}

Selected nodule samples were continuously measured for susceptibility as the temperature was raised from room temperature to $700^{\circ} \mathrm{C}$ and cycled back to $50^{\circ} \mathrm{C}$ in air, with repeated cycles on the same samples (Fig. 7). The behavior of the nodules can be divided into three general classes: those with heating and cooling curves that are not reversible and producing phases other than magnetite, those with nonreversible curves, but producing only magnetite, and curves that are nearly reversible.

\subsubsection{Nonreversible curves with other phases than magnetite}

In these samples heating and cooling curves are not reversible during cycling to $700^{\circ} \mathrm{C}$. On initial heating low susceptibility is measured until $500^{\circ} \mathrm{C}$ when there is an increase of susceptibility with a marked peak occurring at about $560-570{ }^{\circ} \mathrm{C}$, followed by a sharp drop at the Curie point of magnetite (Fig. 7a). The cooling curve displays a strong increase in susceptibility from the Curie temperature of magnetite to $500{ }^{\circ} \mathrm{C}$ followed by a continuous decrease. After the first heating run the susceptibility approximately doubled, suggesting the formation of magnetite within the 
Table 3. Magnetic susceptibility of vivianite nodules.

\begin{tabular}{|c|c|c|c|c|c|}
\hline $\begin{array}{r}\text { Sam- } \\
\text { ple }\end{array}$ & $\begin{array}{r}\text { Depth, } \\
\mathrm{m}\end{array}$ & $\begin{array}{r}\text { Weight, } \\
\text { Nodules } \\
\mathrm{Mg}\end{array}$ & $\begin{array}{r}\text { MS, } \\
10^{-6}, \\
\mathrm{~m}^{3} \mathrm{~kg}^{-1} \\
\text { nodules }\end{array}$ & $\begin{array}{r}\mathrm{MS} \\
10^{-6} \\
\mathrm{~m}^{3} \mathrm{~kg}^{-1} \\
\text { sediment }\end{array}$ & $\begin{array}{l}\text { Mag- } \\
\text { netic } \\
\text { inter- } \\
\text { val }\end{array}$ \\
\hline 24 & 6.13 & 332 & 1.12 & 0.567 & $\mathrm{~L}$ \\
\hline 25 & 6.15 & 651 & 0.940 & 0.607 & $\mathrm{~L}$ \\
\hline 26 & 6.17 & 108 & 0.866 & 0.260 & $\mathrm{~L}$ \\
\hline 43 & 6.51 & 113 & 0.993 & 0.252 & $\mathrm{~L}$ \\
\hline 44 & 6.53 & 180 & 0.993 & 0.248 & $\mathrm{~L}$ \\
\hline 67 & 6.99 & 118 & 0.945 & 0.453 & $\mathrm{~L}$ \\
\hline 68 & 7.01 & 457 & 0.886 & 0.213 & $\mathrm{~L}$ \\
\hline 73 & 7.01 & 170 & 0.810 & 0.388 & $\mathrm{~L}$ \\
\hline 74 & 7.12 & 136 & 0.839 & 0.191 & $\mathrm{~L}$ \\
\hline 159 & 9.35 & 112 & 1.43 & 0.207 & $\mathrm{~L}$ \\
\hline 163 & 9.53 & 156 & 0.919 & 0.453 & $\mathrm{~L}$ \\
\hline 287 & 12.35 & 247 & 1.54 & 2.129 & $\mathrm{H}$ \\
\hline 296 & 12.53 & 200 & 1.288 & 2.655 & $\mathrm{H}$ \\
\hline 297 & 12.55 & 330 & 1.274 & 1.956 & $\mathrm{H}$ \\
\hline 303 & 12.67 & 416 & 0.971 & 0.548 & $\mathrm{~L}$ \\
\hline 361 & 13.97 & 417 & 1.72 & 2.110 & $\mathrm{H}$ \\
\hline 369 & 14.13 & 419 & 1.01 & 1.689 & $\mathrm{H}$ \\
\hline 370 & 14.15 & 551 & 1.12 & 1.606 & $\mathrm{H}$ \\
\hline 385 & 14.57 & 104 & 1.23 & 1.867 & $\mathrm{H}$ \\
\hline 387 & 15.21 & 176 & 1.11 & 2.472 & $\mathrm{H}$ \\
\hline 388 & 15.23 & 303 & 1.03 & 2.559 & $\mathrm{H}$ \\
\hline 389 & 15.25 & 113 & 1.04 & 2.667 & $\mathrm{H}$ \\
\hline 438 & 16.23 & 181 & 1.15 & 2.302 & $\mathrm{H}$ \\
\hline 439 & 16.25 & 254 & 1.08 & 1.781 & $\mathrm{H}$ \\
\hline 445 & 16.37 & 437 & 0.888 & 0.165 & $\mathrm{~L}$ \\
\hline 484 & 17.27 & 2363 & 0.960 & 1.410 & $\mathrm{H}$ \\
\hline 485 & 17.29 & 1082 & 0.844 & 0.311 & $\mathrm{~L}$ \\
\hline 488 & 17.35 & 2854 & 0.787 & 0.171 & $\mathrm{~L}$ \\
\hline 597 & 19.59 & 598 & 0.868 & 0.405 & $\mathrm{~L}$ \\
\hline 620 & 20.05 & 214 & 1.34 & 1.533 & $\mathrm{H}$ \\
\hline 621 & 20.07 & 109 & 1.09 & 0.851 & $\mathrm{H}$ \\
\hline 622 & 20.09 & 1127 & 0.914 & 0.378 & $\mathrm{~L}$ \\
\hline 632 & 20.41 & 360 & 0.878 & 0.296 & $\mathrm{~L}$ \\
\hline 644 & 20.65 & 247 & 0.775 & 0.692 & $\mathrm{~L}$ \\
\hline 683 & 21.58 & 202 & 1.53 & 1.754 & $\mathrm{H}$ \\
\hline 687 & 21.66 & 382 & 1.13 & 1.858 & $\mathrm{H}$ \\
\hline 715 & 22.33 & 122 & 1.06 & 0.145 & $\mathrm{~L}$ \\
\hline 716 & 22.35 & 495 & 0.908 & 0.164 & L \\
\hline 717 & 22.37 & 275 & 0.815 & 0.190 & $\mathrm{~L}$ \\
\hline 725 & 22.59 & 127 & 0.846 & 0.131 & $\mathrm{~L}$ \\
\hline 733 & 22.75 & 124 & 1.15 & 2.105 & $\mathrm{H}$ \\
\hline 754 & 23.17 & 273 & 0.870 & 0.987 & $\mathrm{H}$ \\
\hline 816 & 24.59 & 167 & 1.28 & 2.967 & $\mathrm{H}$ \\
\hline 819 & 24.65 & 170 & 1.07 & 1.360 & $\mathrm{H}$ \\
\hline 822 & 24.71 & 354 & 0.880 & 0.330 & $\mathrm{~L}$ \\
\hline 823 & 24.73 & 1198 & 0.915 & 0.472 & $\mathrm{~L}$ \\
\hline 844 & 25.34 & 145 & 1.44 & 1.937 & $\mathrm{H}$ \\
\hline 845 & 25.36 & 155 & 1.20 & 2.253 & $\mathrm{H}$ \\
\hline 846 & 25.38 & 117 & 1.28 & 2.192 & $\mathrm{H}$ \\
\hline 853 & 25.52 & 165 & 0.927 & 0.222 & $\mathrm{~L}$ \\
\hline 854 & 25.54 & 623 & 0.865 & 0.215 & $\mathrm{~L}$ \\
\hline 855 & 25.56 & 404 & 0.881 & 0.400 & $\mathrm{~L}$ \\
\hline 877 & 26.00 & 198 & 1.03 & 3.141 & $\mathrm{H}$ \\
\hline 878 & 26.02 & 213 & 1.43 & 2.252 & $\mathrm{H}$ \\
\hline 901 & 26.55 & 124 & 0.782 & 0.163 & $\mathrm{~L}$ \\
\hline 937 & 27.37 & 207 & 1.08 & 1.199 & $\mathrm{H}$ \\
\hline
\end{tabular}

L (H) - Low (high) susceptibility intervals.
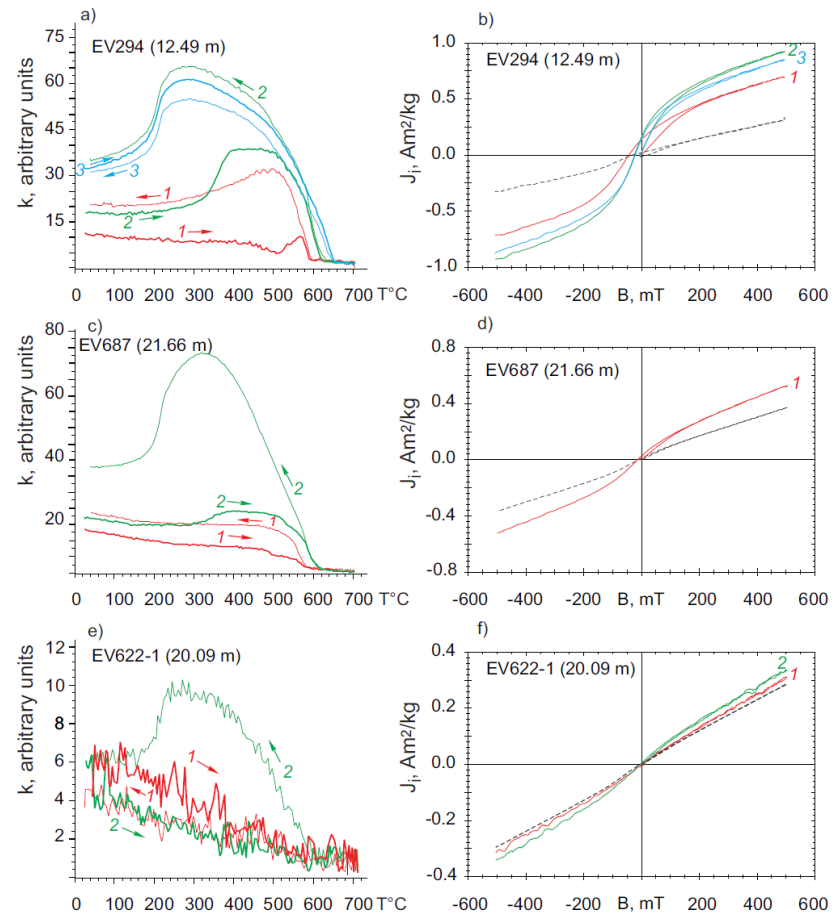

Fig. 7. Susceptibility versus temperature (in air) curves (a, c, e) of representative vivianite samples of groups (the arrows indicate the heating and cooling curves; cursive numbers show the heating and cooling runs) and typical examples of hysteresis loops after heating run (uncorrected for paramagnetism) of vivianite $(\mathbf{b}, \mathbf{d}, \mathbf{f})$ where dashed line indicates.

vivianite sample. The heating curve of the second run displays an increase in susceptibility at $330-350^{\circ} \mathrm{C}$ and a sharp drop at $630^{\circ} \mathrm{C}$ (Fig. 7a). The cooling curves are much higher than the heating curves, with a sharp increase in susceptibility from $630^{\circ} \mathrm{C}$ reaching a maximum at temperatures of 280 $330^{\circ} \mathrm{C}$, before a rapid decrease to room temperature. Heating and cooling curves of the third run are almost reversible and have the same shape as the cooling curve of the second run, but the sharp drop of susceptibility on heating is not complete until $650{ }^{\circ} \mathrm{C}$. Hysteresis data collected after each cycle are shown in Fig. $7 \mathrm{~b}$ and tabulated in Table 4. Coercive force decreases from 50.3 to $20 \mathrm{mT}$ and coercivity of remanence decreases from 91 to $56 \mathrm{mT}$ after heating runs, suggesting the formation of a lower coercivity magnetic phase.

\subsubsection{Nonreversible curves producing magnetite}

In these samples heating and cooling curves are not reversible (Fig. 7c). K-T warming curves show a gradual decrease in susceptibility and a sharp drop close to $580^{\circ} \mathrm{C}$, marking the presence of magnetite. The cooling curves display a strong increase in susceptibility at the Curie temperature of magnetite, with a small but steady increase below $525^{\circ} \mathrm{C}$. After the first heating cycle, susceptibility shows an increase of 1.4 times the original. The heating curve of the 
Table 4. Hysteresis parameters of vivianite nodules.

\begin{tabular}{|c|c|c|c|c|c|c|c|}
\hline Sample & Depth, m & $B_{\mathrm{c}}, \mathrm{mT}$ & $B_{\mathrm{cr}}, \mathrm{mT}$ & $J_{\mathrm{s}}, \mathrm{Am}^{2} \mathrm{~kg}^{-1}$ & $J_{\mathrm{rs}}, \mathrm{Am}^{2} \mathrm{~kg}^{-1}$ & $J_{\mathrm{rs}} / J_{\mathrm{s}}$ & $B_{\mathrm{cr}} / B_{\mathrm{c}}$ \\
\hline EV294 & \multirow{4}{*}{12.49} & 36.54 & 91.36 & 0.35 & 0.03 & 0.09 & 2.5 \\
\hline EV294 1st heating & & 50.32 & 91.72 & 0.37 & 0.16 & 0.44 & 1.82 \\
\hline EV294 2nd heating & & 22.71 & 62.72 & 0.56 & 0.17 & 0.30 & 2.76 \\
\hline EV294 3rd heating & & 20.03 & 56.89 & 0.50 & 0.14 & 0.29 & 2.83 \\
\hline EV-297 & \multirow{6}{*}{12.55} & 26.35 & 90.81 & 0.37 & 0.02 & 0.06 & 3.45 \\
\hline EV297 1st heating & & 34.84 & 75.79 & 0.17 & 0.05 & 0.32 & 2.17 \\
\hline EV297 2nd heating & & 31.24 & 97.78 & 0.28 & 0.10 & 0.36 & 3.13 \\
\hline EV297 + AS 1st heating & & 49.77 & 93.60 & 0.21 & 0.09 & 0.44 & 1.88 \\
\hline EV297+S 1st heating & & 72.68 & 149.30 & 0.20 & 0.08 & 0.40 & 2.05 \\
\hline EV297+S 2nd heating & & 25.53 & 59.45 & 0.69 & 0.20 & 0.29 & 2.32 \\
\hline EV-622-1 1st heating & \multirow{2}{*}{20.09} & 4.40 & 68.01 & 0.02 & 0.002 & 0.10 & \\
\hline EV-622-1 2nd heating & & 21.44 & 107.24 & 0.07 & 0.01 & 0.15 & 5.00 \\
\hline EV687 & \multirow{2}{*}{21.66} & 11.13 & 63.75 & 0.36 & 0.01 & 0.03 & 5.73 \\
\hline EV687 1st heating & & 23.30 & 73.64 & 0.14 & 0.03 & 0.23 & 3.15 \\
\hline EVSM & \multirow{4}{*}{$17.27-17.35$} & 7.33 & 67.24 & 0.34 & 0.01 & 0.02 & 9.17 \\
\hline EVSM + S 1st heating & & 72.24 & 168.87 & 0.51 & 0.10 & 0.19 & 2.34 \\
\hline EVSM + O 1st heating & & 23.59 & 67.73 & 0.09 & 0.02 & 0.25 & 2.87 \\
\hline $\mathrm{EVSM}+\mathrm{N}$ 1st heating & & 51.65 & 102.98 & 0.22 & 0.09 & 0.40 & 1.99 \\
\hline
\end{tabular}

Italic font - parameters uncorrected for paramagnetism.

second run is similar to the heating curve of the second run of the first curve class (Fig. 7a) and displays an increase in susceptibility at $330-350^{\circ} \mathrm{C}$ and a sharp drop at $615^{\circ} \mathrm{C}$. In the cooling path there is a marked increase in susceptibility starting at $615^{\circ} \mathrm{C}$ and reaching a maximum at $320^{\circ} \mathrm{C}$ (Fig. 7c). On continued cooling susceptibility makes a sharp drop before leveling off at a value nearly double the initial susceptibility. Hysteresis behavior after the first heating is shown in Fig. 7d, along with hysteresis parameters listed in Table 4. Ratios of $J_{\mathrm{rs}}$ to $J_{\mathrm{S}}$ and $B_{\mathrm{cr}}$ to $B_{\mathrm{c}}$ plot within the pseudo-single-domain field of Day et al. (1977).

\subsubsection{Nearly reversible curves}

For the sample shown in Fig. 7e, the initial heating and cooling curves of the first run are almost reversible. There is a decrease in susceptibility up to $700^{\circ} \mathrm{C}$, with a cooling curve that is slightly lower but not markedly different. Susceptibility here includes up to $85 \%$ due to a paramagnetic component, producing a noisy curve. Curie points of neither magnetite nor hematite are clearly visible on the graph. The heating curve for the second run is very similar to the first cooling curve. But, a marked change is observed in the second cooling run, with a strong increase in susceptibility observed at $620^{\circ} \mathrm{C}$, reaching its maximum at $270^{\circ} \mathrm{C}$, followed by a sharp decrease (Fig. 7e). Hysteresis behaviors after the first and second runs are plotted in Fig. 7f. There are moderate increases in $B_{\mathrm{c}}$ and $B_{\mathrm{cr}}$ from the first heating run to the second run (Table 4 ). The $B_{\mathrm{cr}} / B_{\mathrm{c}}$ and $J_{\mathrm{rs}} / J_{\mathrm{S}}$ ratios after second heat-

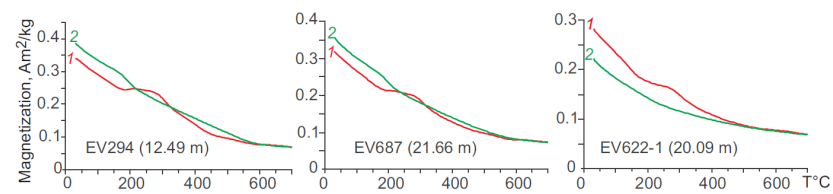

Fig. 8. Induced magnetization versus temperature curves of representative vivianite samples. Cursive numbers show the heating runs.

ing suggest formation of a superparamagnetic domain magnetic phase.

\subsection{Induced magnetization versus temperature}

Additional material from three samples discussed above was also studied for the behavior of magnetization $\left(J_{\mathrm{i}}\right)$ with heating to $700^{\circ} \mathrm{C}$ (Fig. 8). The initial heating curve for each sample shows a small but distinctive "hump" marked by change in slope or a slight increase in $J_{\mathrm{i}}$ at $180-200^{\circ} \mathrm{C}$ and a decrease at $320-340^{\circ} \mathrm{C}$. There is, additionally, a slight hint of a minor increase in $J_{\mathrm{i}}$ at $580^{\circ} \mathrm{C}$ (Fig. 8). The second set of heating curves shows no humps, but continuous decay of the magnetization with increased temperature to $580^{\circ} \mathrm{C}$ after which the curves appear to flatten out.

In comparing the high-temperatures curves of MS of the first heating run (Fig. 7a, c, e) to the induced magnetization of first heating (Fig. 8a, b, c), several differences are noted. The visible increase in susceptibility at $500{ }^{\circ} \mathrm{C}$ for sample EV294 (Fig. 7a) is not observed on the $J_{\mathrm{i}}$ heating curve (Fig. 8a); the humps visible on all the initial curves of magnetization with 

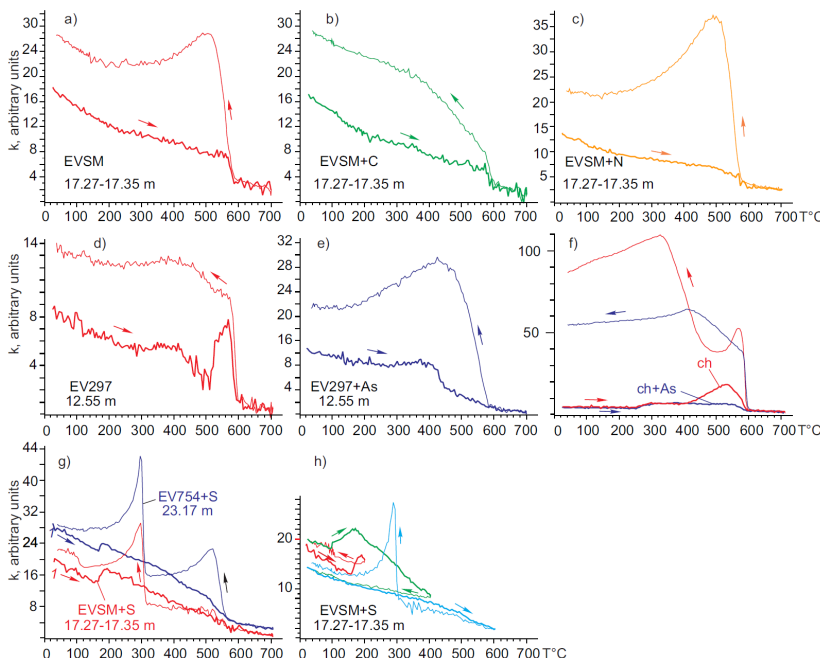

Fig. 9. Susceptibility versus temperature curves: (a, d) - in air; (b) - with sucrose; (c) - with carbamide; (e) - with arsenic; (f) chalcopyrite heating in air $(\mathrm{ch})$ and with arsenic $(\mathrm{ch}+\mathrm{As}) ;(\mathbf{g}, \mathbf{h})-$ with sulfur. The arrows indicate the heating and cooling runs.

temperature (Fig. 8) are nowhere evident on initial heating curves of susceptibility (Fig. 7).

\subsection{High-temperature behavior of vivianite with additive material}

To further investigate the behavior of the vivianite nodules with other common materials in lake sediments, we studied high-temperature susceptibility of vivianite mixed with sucrose (organic carbon), carbamide (nitrogen), metallic powder of arsenic, and elemental sulfur.

No difference is seen in the heating curves for crushed vivianite samples without additive or those with sucrose or carbamide added (Fig. 9a, b, c). All the heating curves show small but distinct drops near $580^{\circ} \mathrm{C}$. Cooling curves all show a considerable increase in susceptibility starting at $580^{\circ} \mathrm{C}$, with a continued increase to sharp peaks around $500^{\circ} \mathrm{C}$, and then decay as temperature decreases for the plain vivianite and the vivianite plus carbamide samples. The vivianite and sucrose sample also increases below $580^{\circ} \mathrm{C}$, but continues to increase up to room temperature. All samples finish with susceptibility 1.5 to 2 times higher than the initial value.

A vivianite sample representative of first type K-T nonreversible curves with increased MS during heating was heated with arsenic. The initial vivianite run (Fig. 9d) has a large increase in susceptibility between $500^{\circ}-600^{\circ} \mathrm{C}$, indicating the formation of magnetite. When heated with arsenic this increase is not seen, although a small increase occurred at lower temperatures around $400^{\circ} \mathrm{C}$ (Fig. 9e). It appears that arsenic suppresses the formation of magnetite prior to the Curie temperature. The cooling curve for the arsenic-added sample indicates the formation of magnetite between $580^{\circ} \mathrm{C}$ and $700^{\circ} \mathrm{C}$ and shows a steep increase to $450^{\circ}-500^{\circ} \mathrm{C}$ as
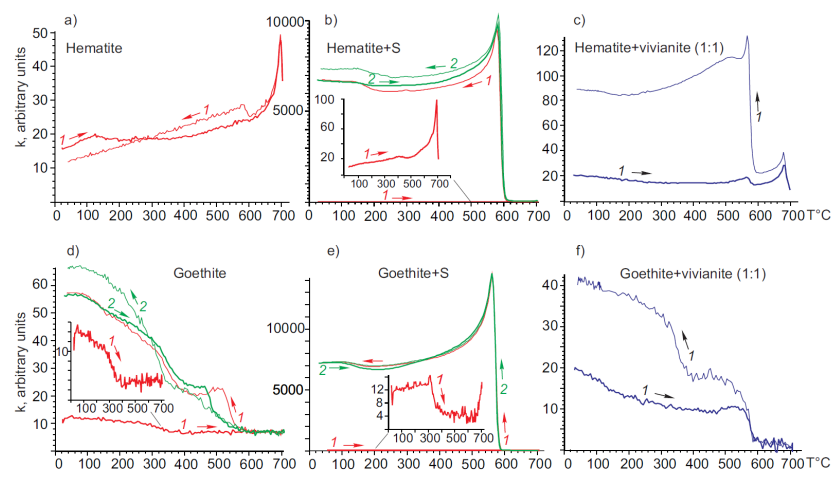

Fig. 10. Susceptibility versus temperature curves of hematite and goethite mixed with sulfur and with vivianite $(1: 1)$. The arrows and cursive numbers indicate the heating and cooling runs.

seen in the previous examples. A similar result of arsenic suppressing magnetite formation can be observed in the heating curves of plain chalcopyrite and chalcopyrite with arsenic (Fig. 9f).

There is a noticeable increase in susceptibility at 150 $170^{\circ} \mathrm{C}$ on the heating curves of vivianite with added sulfur (Fig. 9g). On cooling, increases in susceptibility are seen at Curie temperature of magnetite and monoclinic pyrrhotite. Heating the vivianite and sulfur mixture to temperatures of 200,400 and $600^{\circ} \mathrm{C}$ and cooling each time, shows that all heating and cooling curves are irreversible (Fig. 9h). The formation of pyrrhotite is seen only after the final $600{ }^{\circ} \mathrm{C}$ heating and cooling run. On all these runs the final susceptibility increases, but always less than a factor of 2 .

There are very different heating results when sulfur is added to goethite or hematite (Fig. 10b, e). After heating hematite and goethite with sulfur, susceptibility increases between 400 and 610 times. The newly formed mineral is magnetite, indicated by the large increase in susceptibility at $580^{\circ} \mathrm{C}$ (Minyuk et al., 2011).

Mixtures of vivianite and either hematite or goethite show vivianite to play the reducing role, but less than sulfur does. Heating a hematite and vivianite mixture $(1: 1)$ shows that during heating magnetite is formed (Fig. 10c). On cooling the susceptibility curve sharply increases at both $580^{\circ} \mathrm{C}$ and $685^{\circ} \mathrm{C}$, producing marked Hopkinson peaks for magnetite and hematite. The final MS increases four-fold after the heating and cooling cycle. Goethite-vivianite mixture shows the same cooling curves as for pure goethite, but without visible goethite-hematite transition at temperature $360^{\circ} \mathrm{C}$ on heating curves (Fig. 10f). There is a small increase in susceptibility at $470^{\circ} \mathrm{C}$ and the expected large drop at $580^{\circ} \mathrm{C}$. On cooling, both the $580^{\circ} \mathrm{C}$ and $360^{\circ} \mathrm{C}$ increases are noted, with final susceptibility again being four-fold larger than the initial.

Mixtures of pyrite and vivianite were also tested to further investigate changes in oxide mineralogy. The K-T curve of pyrite (Fig. 11a) is very similar to the heating and cooling curves of a $1: 1$ mixture of vivianite and pyrite (Fig. 11b). 


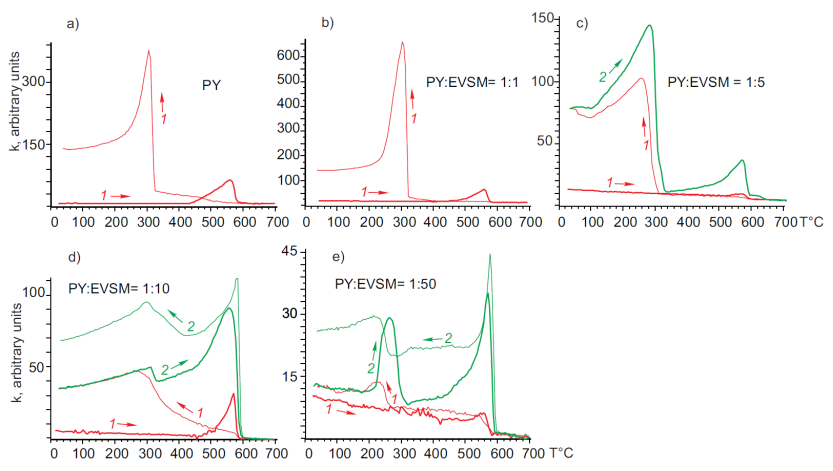

Fig. 11. Susceptibility versus temperature curves of pyrite and vivianite mixtures. The arrows and cursive numbers indicate the heating and cooling runs. PY - pyrite, EVSM - vivianite.

Very similar curves are also obtained when the mixture is $1: 5$ (Fig. 11c). In this case the Hopkinson peaks of monoclinic pyrrhotite are higher than magnetite ones. Cooling curves of mixture $1: 10$ are different, with no sharp increase in susceptibility at monoclinic pyrrhotite Curie temperature obvious (Fig. 11d). Susceptibility gradually increases from 600 to $280^{\circ} \mathrm{C}$ on cooling, but on a second run heating curve there is a decrease in susceptibility at Curie temperature of monoclinic pyrrhotite. Distinct Hopkinson peaks of magnetite are observed on all curves of second runs.

K-T curves of mixture $1: 50$ yield another set of very different results (Fig. 11e). On cooling of the first run, susceptibility increases at $280^{\circ} \mathrm{C}$; the same increase is seen on the cooling curve of second run. Such increase suggests a formation of hexagonal pyrrhotite during cooling. During the second heating run, the hexagonal pyrrhotite transforms into monoclinic pyrrhotite, showing increased susceptibility at $220^{\circ} \mathrm{C}$ and a drop at $300-320^{\circ} \mathrm{C}$ (Fig. 11e). This may reflect the so-called $\lambda$-transition from antiferro- to ferromagnetic behavior as described by Dekkers (1989b), and Kontny et al. (2000). On the cooling curves of both runs, no increase in susceptibility at the Curie temperature of monoclinic pyrrhotite is visible. Sharp magnetite Hopkinson peaks are evident on the heating and cooling curves of the second runs.

\section{Discussion}

\subsection{Environmental significance of vivianite}

In Lake El'gygytgyn sediment vivianite is the more abundant authigenic mineral among other iron-bearing minerals such as pyrite, greigite, siderite, and $\mathrm{Fe}-\mathrm{Mn}$ aggregates. The nodules and concretions of vivianite amount to a few grams per sample along the core profile (weight of sample is 6 grams in average). Morphological features of nodules are variable, suggesting different growth conditions. Some nodules are empty or filled with crystals in central parts, indi- cating growth of the concretions from the surface towards the center. Other nodules consist of crystal clusters with randomly oriented fragile crystals, suggesting that nodules formed before sediment compaction.

Large nodules were found in sediments of cold (anoxic) and warm (oxic) climate stages, indicating that formation of nodules is not controlled by large-scale climate oscillations (Fig. 3). Vivianite nodules are distributed in different lithological facies A, B, C representing glacial (dark gray to black finely laminated silt and clay), interglacial (olive gray to brownish massive to faintly banded silt) and "super" interglacial (finely laminated reddish-brown silt) periods (Melles et al., 2012). Nodule occurrence appears to be controlled by the diagenetic microenvironment (Stoops, 1983; Stamatakis and Koukouzas, 2001); anoxic microenvironments are often found around fossil fish bones and organic detritus.

Other distributions seen as spikes of $\mathrm{P}_{2} \mathrm{O}_{5}, \mathrm{MnO}$ and $\mathrm{Fe}_{2} \mathrm{O}_{3}$ occur along the depth profile (Fig. 3). In general, enrichment in these elements is in cold (anoxic) stage sediments as 6.2. 6.4, 6.6, 7.4, 8.4, partly 10 and 12 , and in anoxic layers of 11.3. Often spikes of $\mathrm{Fe}_{2} \mathrm{O}_{3}$ coincide with maximum $\mathrm{MnO} / \mathrm{Fe}_{2} \mathrm{O}_{3}$ ratios, indicating reducing conditions in the lake (Mackereth, 1966).

Magnetic behavior of vivianite nodules is important to overall interpretation of magnetic archives of lacustrine sediments that are used as environmental proxies. In the study of Lake El'gygytgyn, MS is an important parameter, and is used for core description, correlation, and dating (Melles et al., 2012; Nowaczyk et al., 2007, 2013). Vivianite is paramagnetic at room temperature and becomes antiferromagnetic (weakly magnetic) only at low temperatures $(<20 \mathrm{~K})$. But, samples studied here show that the nodules have magnetic susceptibilities similar to many of the bulk sediments, and often higher than the susceptibility of sediments from cold intervals. For example, MS in general shows low values in stage 6, but at depths 7.05-7.26 $\mathrm{m}$ and 9.13-9.33 $\mathrm{m} \mathrm{MS}$ has slightly increased (Fig. 3). Simultaneously, this depth is enriched in $\mathrm{P}_{2} \mathrm{O}_{5}$ and $\mathrm{MnO}$ that may enhance the formation of vivianite. Correlation coefficients between $\mathrm{P}_{2} \mathrm{O}_{5}$ and $\mathrm{MS}$ in intervals $7.05-7.26 \mathrm{~m}$ and $9.13-9.33 \mathrm{~m}$ are 0.47 and 0.68 , respectively. In stage 7.4 at depth $11.59-12.19 \mathrm{~m}$, the high $\mathrm{P}_{2} \mathrm{O}_{5}$ content positively correlates with increased MS values $(r=0.58)$, indicating fine-grained vivianite is also present. Large vivianite nodules are absent in Fe-P-Mn intervals, suggesting possible precipitation of vivianite directly from lake water (e.g., Dean, 2002) that can be related to events of climate and environmental change.

In most cases vivianite concretions are not homogeneous, but contain irregular oxidized patches. In backscattered electron images the oxidized parts have lighter color and record higher $\mathrm{Fe}$ and $\mathrm{P}$ content (Fig. 5a, b). The oxidized parts are often located along cracks and in outer parts of nodule grains, and possibly consist of metavivianite or santabarbaraite. Some oxidation spots are depleted in Mn, as was reported by Fagel et al. (2005) for Baikal vivianite. On 
the other hand, Pratt (1997) reports that the product of vivianite auto-oxidation on cleaved surfaces is ferric hydroxide. Sapota et al. (2006) mention that some Baikal vivianite microconcretions are covered with yellow-brown iron oxides, likely goethite. In a calcareous medium, vivianite is oxidized to poorly crystalline lepidocrocite (Roldán et al., 2002). However, the products of oxidation appear to have little influence on the magnetic properties of vivianite due to the weak MS of any of the oxidation products.

Lepidocrocite is paramagnetic at room temperature with a low-field susceptibility of $57.8 \times 10^{-8} \mathrm{~m}^{3} \mathrm{~kg}^{-1}$ (e.g., Hirt et al., 2002), goethite is antiferromagnetic with susceptibility $0.5-1.5 \times 10^{-6} \mathrm{~m}^{3} \mathrm{~kg}^{-1}$ (e.g., Dekkers, 1989a). MS of nodules $(n=54)$ exhibit values between $0.78 \times 10^{-6} \mathrm{~m}^{3} \mathrm{~kg}^{-1}$ and $1.72 \times 10^{-6} \mathrm{~m}^{3} \mathrm{~kg}^{-1}$ (average $=1.05 \times 10^{-6} \mathrm{~m}^{3} \mathrm{~kg}^{-1}$ ). Numerous nodules include grains of sulfides, ilmenite, iron, titanomagnetite, and/or clay minerals; magnetic susceptibility could be increased and magnetic inclusions could even increase the attraction of nodules to a magnet. Positive correlation between MS of nodules and MS of sediment suggests that during growth the nodules capture grains from sediments. But this included material is a secondary source of MS because the susceptibility of the nodules is higher than that of the sediment from low-magnetic intervals.

\subsection{Interpretation of thermomagnetic data}

Investigations of the behavior of vivianite upon cyclic heating and cooling reveal the mineralogical changes that can occur in this system. The formation of new mineral phases - predominantly magnetite and/or hematite - occurs when vivianite samples are repeatedly heated and cooled between room temperature and $700^{\circ} \mathrm{C}$. Such conditions occur in nature during peat deposit fires, where vivianite often occurs (Matukhina et al., 1986).

There are three types of K-T curves (Fig. 7). The characteristic features of all vivianite nodules are observed in the cooling curves of second and third runs. These curves show an increase in susceptibility from $620-650^{\circ} \mathrm{C}$ to $250-300^{\circ} \mathrm{C}$ followed by a sharp drop.

$J_{\mathrm{i}}-T$ curves show increased $J_{\mathrm{i}}$ during heating at temperatures from $180-200^{\circ} \mathrm{C}$ (Fig. 8). The hump on the curves possibly reflects the dehydration of vivianite and the ensuing oxidation of $\mathrm{Fe}^{2+}$.

For interpretation of TMA results we use data from the literature of differential thermal analyses. Natural vivianite shows weight loss steps at $105,138,203,272$ and $437^{\circ} \mathrm{C}$ that are attributed to dehydration (Frost et al., 2003). Marincea et al. (1997) point out that endothermic peaks recorded on the differential thermal analysis DTA curve at temperatures of $183^{\circ} \mathrm{C}$ and $205^{\circ} \mathrm{C}$ mark a major loss of structurally bound $\mathrm{H}_{2} \mathrm{O}$ and the beginning of oxidation of $\mathrm{F}^{2+}$ to $\mathrm{Fe}^{3+}$. The exothermic peak recorded on the DTA curve at $270{ }^{\circ} \mathrm{C}$ corresponds to another phase of oxidation. Rodgers and Henderson (1986) report the loss of structural water combined with the oxidation of $\mathrm{Fe}^{2+}$ spanning 65 to $315^{\circ} \mathrm{C}$, and the formation of alpha- $\mathrm{FePO}_{4}, \mathrm{Fe}\left(\mathrm{PO}_{3}\right)_{3}$ and, occasionally, $\mathrm{Fe}_{2} \mathrm{O}_{3}$, as marked on DTA curve at $660^{\circ} \mathrm{C}$. On K-T curves there are no visible signs of dehydration of vivianite at these temperatures, indicating that this process does not influence MS.

K-T curves of the first type show increased susceptibility on heating at temperature of $500^{\circ} \mathrm{C}$ (Fig. 7a). The hump on heating curves is possibly attributed to the transformation of sulfides from pyrite to magnetite during heating. But pyrite transformation during heating usually begins at temperatures of $420-450{ }^{\circ} \mathrm{C}$ and forms magnetite and monoclinic pyrrhotite (e.g., Wang et al., 2008; Tanikawa et al., 2008). Thermomagnetic study of vivianite and pyrite mixtures shows that, depending on the mixture composition, monoclinic or hexagonal pyrrhotite is produced (Fig. 11). In our case, neither monoclinic pyrrhotite (high pyrite content) nor hexagonal pyrrhotite (low pyrite content) form.

A plausible explanation can be obtained with goethite as an oxidation product of vivianite. Goethite shows no such hump on heating curves (Fig. 10d), but on heating a mixture of vivianite and goethite a similar increase in susceptibility is seen after $500^{\circ} \mathrm{C}$ (Fig. 10f).

Continued cycling of samples from the first type shows in the second run drop of MS at $\sim 620^{\circ} \mathrm{C}$. On the third run the temperature has increased to $650^{\circ} \mathrm{C}$. If this is indicative of a Curie temperature $\left(630-650^{\circ} \mathrm{C}\right)$, it is lower than that of hematite and closer to that of maghemite (Özdemir, 1990; Gehring et al., 2009). According to $J_{\mathrm{rs}} / J_{\mathrm{s}}$ and $B_{\mathrm{cr}} / B_{\mathrm{c}}$ ratios pseudo-single-domain particles were formed during the first heating (Day et al., 1977). The decrease of $B_{\mathrm{c}}$ and $B_{\mathrm{cr}}$ after few cycles of heating and cooling, a decrease in $J_{\mathrm{rs}} / J_{\mathrm{s}}$, and an increase in $B_{\mathrm{cr}} / B_{\mathrm{c}}$ indicate the formation of lower coercivity minerals and larger domain-state particles (Table 4, sample EV294).

Thermomagnetic data show that quantities of magnetic minerals are not generated during heating and cooling. MS does not increase by more than two-fold after heating.

\subsection{Influence heating media and Fe-bearing minerals on thermomagnetic properties of vivianite nodules}

The behavior of the susceptibility of vivianite upon heating with organic carbon, nitrogen, sulfur and arsenic was monitored. The same as vivianite, these additives occur in Lake El'gygytgyn sediments of cold (anoxic) stages, and may influence on high-temperature properties of vivianite. Vivianite mixed with sucrose (organic carbon) or carbamide (nitrogen) shows similar thermomagnetic curves to vivianite without the additive. Arsenic suppresses the generation of magnetite at temperatures lower than the Curie temperature of this mineral $\left(578^{\circ} \mathrm{C}\right)$. But, magnetite that formed at higher temperature is of the same amount as that which had formed after heating vivianite with sucrose and carbamide.

Specific thermomagnetic curves are produced for vivianite mixed with elemental sulfur. All first heating curves 
show a small hump in susceptibility at temperatures of 150 $170{ }^{\circ} \mathrm{C}$. Interpretation of this hump is highly ambiguous. Such increase in susceptibility may reflect $\lambda$-transition from antiferro- to ferromagnetic behavior of pyrrhotite. Kontny at al. (2000) report temperatures of $160^{\circ}-210^{\circ} \mathrm{C}$ for this transition. According to Li and Franzen (1996), thermomagnetic heating-cooling curves for a peak-type pyrrhotite in the temperature range between 20 and $400{ }^{\circ} \mathrm{C}$ are reversed from this. Our data indicate that the mineral phase formed here is unstable. K-T curves after heating to $200^{\circ} \mathrm{C}$ and to $400^{\circ} \mathrm{C}$ exhibit irreversible thermomagnetic behaviors (Fig. 9h). A plausible explanation is that the hump reflects the dehydration of vivianite that was invisible without sulfur.

After heating the sulfur-vivianite mixture to $600^{\circ} \mathrm{C}$, monoclinic pyrrhotite, marked by Hopkinson peak on cooling curve at a temperature $320^{\circ} \mathrm{C}$, is formed.

Such behavior is different from thermomagnetic curves of hematite and goethite mixtures with sulfur showing formation of magnetite in large amounts (Fig. 10b, e).

Thermomagnetic data are widely used to diagnose magnetic minerals, but heating media and the presence of other minerals in the samples can complicate interpretation of the results. The influence of vivianite on the thermomagnetic behavior of hematite, goethite and pyrite was investigated. Hematite-vivianite mixture $(1: 1)$ shows that vivianite acts as a reductant and stimulates formation of magnetite (Fig. 10c). During heating of the goethite-vivianite mixture $(1: 1)$, the vivianite masks the goethite-hematite transition but stimulates the formation of magnetite (Fig. 10f). Behavior of a pyrite and vivianite mixture during heating depends on the specific pyrite-vivianite content. Thermomagnetic curves for mixtures with vivianite content up to $80 \%$ are nearly similar to those for pyrite (Fig. 11a, b, c). Pyrite-vivianite mixing ratio $1: 10$ show formation of magnetite and monoclinic pyrrhotite during heating but lacking the sharp Hopkinson peak of pyrrhotite on cooling. A second heating run produces more magnetite. Heating and cooling of a pyrite-vivianite mixture $(1: 50)$ exhibits the formation of hexagonal pyrrhotite. This pyrrhotite is unstable during a second heating and transforms into unstable monoclinic pyrrhotite and magnetite, as seen on the cooling curve of the second run.

\section{Conclusions}

Vivianite nodules are abundant in both sediments of cold (anoxic) and warm (oxic) stages. MS of vivianite nodules varies from $0.78 \times 10^{-6} \mathrm{~m}^{3} \mathrm{~kg}^{-1}$ to $1.72 \times 10^{-6} \mathrm{~m}^{3} \mathrm{~kg}^{-1}$ (average $=1.05 \times 10^{-6} \mathrm{~m}^{3} \mathrm{~kg}^{-1}$ ) and is higher than the susceptibility of sediments from cold intervals. This susceptibility of vivianite can then obscure the environmental signal determined from rock magnetic properties.
Magnetic properties of vivianite are due to respective products of oxidation as well as sediment and mineral inclusions.

There are three types of curves of high-temperature versus susceptibility for vivianite indicating different degrees of oxidation and inclusions in nodules.

Vivianite acts as a reductant and reduces hematite to magnetite, while also masking the goethite-hematite transition during heating.

Adding sulfur to vivianite stimulates formation of monoclinic pyrrhotite, whereas the addition of arsenic suppresses the formation of magnetite below its Curie temperature.

Heating selective vivianite and pyrite mixtures shows formation of different minerals - magnetite, monoclinic pyrrhotite, and hexagonal pyrrhotite - that make it difficult to interpret the thermomagnetic curves.

Acknowledgements. Drilling operations were funded by the ICDP, the NSF, the German Federal Ministry of Education and Research (BMBF), Alfred Wegener Institute and Helmholtz Centre Potsdam (GFZ), Far East Branch of the Russian Academy of Sciences (FEB RAS), the Russian Foundation for Basic Research (RFBR), and the Austrian Federal Ministry of Science and Research. The Russian Global Lake Drilling 800 drilling system was developed and operated by DOSECC. Funding of sample analyses was provided by the Civilian Research and Development Foundation (grant RUG1-2987-MA-10), RFBR (grant 12-05-00286), FEB RAS (12-II-SB-08-024; 12-III-A-08-191; 12-III-V-08-191). We thank an anonymous reviewer and M. J. Dekkers for their suggestions which greatly improved the paper.

Edited by: M. Melles

\section{References}

Asikainen, C. A., Francus, P., and Brigham-Grette, J.: Sedimentology, clay mineralogy and grain-size as indicators of $65 \mathrm{ka}$ of climate change from El'gygytgyn Crater lake, Northeastern Siberia, J. Paleolimnol., 37, 105-122, 2007.

Bassinot, F. C., Labeyrie, L. D., Vincent, E., Quidelleur, X., Shackleton, N. J., and Lancelot, Y.: The astronomical theory of climate and the age of the Brunhes-Matuyama magnetic reversal, Earth Planet. Sci. Lett, 126, 91-108, 1994.

Bely, V. F. and Belaya, B. V.: Late stage of the OCVB development (upstream of the Enmyvaam River), NEISRI FEB RAS Press, Magadan, 1998 (in Russian).

Bely, V. F. and Raikevich, M. I.: The El'gygytgyn lake basin (geological structure, morphostructure, impactites, problems of investigation and preservation of nature), NEISRI FEB RAS Press, Magadan, 1994 (in Russian).

Borkhodoev, V. Ya.: Accuracy of the fundamental parameter method for $\mathrm{x}$-ray fluorescence analysis of rocks, X-Ray Spectrom., 31, 209-218, 2002.

Brigham-Grette, J., Melles, M., Minyuk, P., and Scientific Party: Overview and significance of a $250 \mathrm{ka}$ paleoclimate record from El'gygytgyn Crater Lake, NE Russia, J. Paleolimnol., 37, 1-16, 2007. 
Burov, B. V., Nourgaliev, D. K., and Yasonov, P. G.: Paleomagnetic analysis, KGU Press, Kazan, 1986 (in Russian).

Day, R., Fuller, M., and Schmidt, V. A.: Hysteresis properties of titanomagnetites: grain size and composition dependence, Phys. Earth Planet. Int., 13, 260-267, 1977.

Dean, W.: A 1500-year record of climatic and environmental change in Elk Lake, Clearwater County, Minnesota II: geochemistry, mineralogy, and stable isotopes, J. Paleolimnol., 27, 301-319, 2002.

Dekkers, M. J.: Magnetic properties of natural goethite-I. Grain-size dependence of some low- and high-field related rock magnetic parameters measured at room temperature, Geophys. J., 97, 323340, 1989a.

Dekkers, M. J.: Magnetic properties of natural pyrrhotite. II Highand low-temperature behavior of Jrs and TRM as function of grain size, Phys. Earth Planet. Int., 57, 266-283, 1989 b.

Fagel, N., Alleman, L. Y., Granina, L., Hatert, F., Thamo-Bozso, E., Cloots, R., and Andre, L.: Vivianite formation and distribution in Lake Baikal sediments, Glob. Planet. Change, 46, 315-336, 2005.

Frederichs, T., von Dobeneck, T., Bleil, U., and Dekkers, M. J.: Towards the identification of siderite, rhodochrosite, and vivianite in sediments by their low-temperature magnetic properties, Phys. Chem. Earth, 28, 669-679, 2003.

Frost, R. L., Weier, M. L., Martens, W., Kloprogge, J. T., and Ding, Z.: Dehydration of synthetic and natural vivianite, Thermochim. Acta, 401, 121-130, 2003.

Gehring, A. U., Fischer, H., Louvel, M., Kunze, K., and Weidler, P. G.: High temperature stability of natural maghemite: a magnetic and spectroscopic study, Geophys. J. Int., 179, 1361-1371, 2009.

Glushkova, O. Yu.: Geomorphological correlation of Late Pleistocene glacial complexes of Western and Eastern Beringia, Quaternary Sci. Rev., 20, 405-417, 2001.

Gurov, E. P., Koeberl, C., and Yamnichenko, A.: El'gygytgyn impact crater, Russia: structure, tectonics, and morphology, Meteorit. Planet. Sci., 42, 307-319, 2007.

Hirt, A. M., Lanci, L., Dobson, J., Weidler, P., and Gehring, A. U.: Low-temperature magnetic properties of lepidocrocite, J. Geophys. Res., 107, 2011, doi:10.1029/2001JB000242, 2002.

Hrouda, F.: A technique for the measurement of thermal changes of magnetic susceptibility of weakly magnetic rocks by the CS-2 apparatus and KLY-2 Kappabridge, Geophys. J. Int., 118, 604612, 1994.

Hrouda, F., Chlupacova, M., and Mrazova, S.: Low-field variation of magnetic susceptibility as a tool for magnetic mineralogy of rocks, Phys. Earth Planet. Int., 154, 323-336, 2006.

Kontny, A., De Wall, H., Sharp, T. G., and Posfai, M.: Mineralogy and magnetic behavior of pyrrhotite from a $260^{\circ} \mathrm{C}$ section at the KTB drilling site, Germany, Am. Min., 85, 1416-1427, 2000.

Layer, P.: Argon-40/argon-39 age of the El'gygytgyn impact event, Chukotka, Russia, Meteorit. Planet. Sci., 35, 591-599, 2000.

Li, F. and Franzen, H. F.: Ordering, Incommensuration, and Phase Transitions in Pyrrhotite. Part II: A High-Temperature X-Ray Powder Diffraction and Thermomagnetic Study, J. Solid State Chem., 126, 108-120, 1996.

Mackereth, F. J. H.: Some chemical observations on post-glacial lake sediments, Phil. Trans. Roy. Soc., Ser. B, 256, 165-213, 1966.
Manning, P. G., Murphy, T. P., and Prepas, E. E.: Intensive formation of vivianite in the bottom sediments of mesotrophic Narrow Lake, Alberta, Can. Min., 29, 77-85, 1991.

Manning, P. G., Prepas, E. E., and Serediak, M. S.: Pyrite and vivianite intervals in the bottom sediments of eutrophic Baptiste Lake, Alberta, Canada, Can. Min., 37, 593-601, 1999.

Marincea, S., Constantinescu, E., and Ladriere, J.: Relatively unoxidized vivianite in limnic coal from Capeni Baraolt Basin, Romania, Can. Min., 35, 713-722, 1997.

Matukhina, V. G., Grigor'eva, T. R., Altukhov, V. M., and Rusanov, D. K.: The peaty vivianites and vivianite peats of the Suzun area in Novosibirsk, Sov. Geol. Geophys., 27, 49-53, 1986.

Meijer, H. C., van den Handel, J., and Frikkee, E.: Magnetic behavior of vivianite, $\mathrm{Fe}_{3}\left(\mathrm{PO}_{4}\right)_{2} \cdot 8 \mathrm{H}_{2} \mathrm{O}$, Physica, 34, 475-48, 1967.

Melles, M., Brigham-Grette, J., Glushkova, O. Yu., Minyuk, P., Nowaczyk, N., and Hubberten, W.: Sedimentary geochemistry of a pilot core from Lake El'gygytgyn - a sensitive record of climate variability in the East Siberian Arctic during the past three climate cycles, J. Paleolimnol., 37, 89-104, 2007.

Melles, M., Brigham-Grette, J., Minyuk, P., Koeberl, C., Andreev, A., Cook, T., Fedorov, G., Gebhardt, C., Haltia-Hovi, E., Kukkonen, M., Nowaczyk, N., Schwamborn, G., Wennrich, V., and the El'gygytgyn Scientific Party: The Lake El'gygytgyn Scientific Drilling Project - Conquering Arctic Challenges through Continental Drilling, Scientific Drilling, 11, 29-40, 2011.

Melles, M., Brigham-Grette, J., Minyuk, P. S., Nowaczyk, N. R., Wennrich, V., DeConto, R. M., Anderson, P. M., Andreev, A. A., Coletti, A., Cook, T. L., Haltia-Hovi, E., Kukkonen, M., Lozhkin, A. V., Rosén, P., Tarasov, P., Vogel, H., and Wagner, B.: 2.8 Million Years of Arctic Climate Change from Lake El'gygytgyn, NE Russia, Science, 337, 315-320, 2012.

Minyuk, P. S., Brigham-Grette, J., Melles, M., Borkhodoev, V. Ya., and Glushkova, O. Yu.: Inorganic geochemistry of El'gygytgyn Lake sediments (northeastern Russia) as an indicator of paleoclimatic change for the last $250 \mathrm{kyr}$, J. Paleolimnol., 37, 123-133, 2007.

Minyuk, P. S., Subbotnikova, T. V., and Plyashkevich, A. A.: Measurements of thermal magnetic susceptibility of hematite and goethite, Izvestia, Phys. Solid Earth, 47, 762-774, 2011.

Minyuk, P. S., Borkhodoev, V. Ya., and Wennrich, V.: Inorganic data from El'gygytgyn Lake sediments: stages 6-11, Clim. Past Discuss., 9, 393-433, doi:10.5194/cpd-9-393-2013, 2013.

Murdock, K. J., Wilkie, K. M., and Brown, L. L.: Rock magnetic properties, magnetic susceptibility, and organic geochemistry comparison in core LZ1029-7 Lake El'gygytgyn, Far Eastern Russia, Clim. Past Discuss., 8, 4565-4599, doi:10.5194/cpd8-4565-2012, 2012.

Nembrin, G. P., Capobianco, J. A., Viel, M., and Williams A. F.: A Mössbauer and chemical study of the formation of vivianite in sediments of Lago Maggiore (Italy), Geochim. Cosmochim. Acta, 47, 1459-1464, 1983.

Nolan, M. and Brigham-Grette, J.: Basic hydrology, limnology, and meteorology of modern Lake El'gygytgyn, Siberia, J. Paleolimnol., 37, 17-35, 2007.

Nowaczyk, N. R., Minyuk, P., Melles, M., Brigham-Grette, J., Glushkova, O. Yu., Nolan, M., Lozhkin, A., Stetsenko, T. V., Anderson, P, and Forman, S. L.: Magnetostratigraphic results from impact crater Lake El'gygytgyn, north-eastern Siberia: a $300 \mathrm{kyr}$ long high-resolution terrestrial paleoclimatic record from 
the Arctic. Geophys. J. Int., 150, 109-126, 2002.

Nowaczyk, N. R., Melles, M., and Minyuk, P.: A revised age model for core PG1351 from Lake El'gygytgyn, Chukotka, based on magnetic susceptibility variations tuned to northern hemisphere insolation variations, J. Paleolimnol., 37, 65-76, 2007.

Nowaczyk, N. R., Haltia-Hovi, E. M., Ulbricht, D., Wennrich, V., Kukkonen, M., Rosen, P., Vogel, H., Meyer-Jacob, C., Andreev, A., Lozhkin, A. V., and El'gygytgyn Scientific Party: Chronology of lake El'gygytgyn sediments, Clim. Past, in preparation, 2013.

Nriagu, J. O. and Dell, C. I.: Diagenetic formation of iron phosphates in recent lake sediments, Am. Min., 59, 934-946, 1974.

Özdemir, Ö.: High-temperature hysteresis and thermoremanence of single-domain maghemite, Phys. Earth Planet. Int., 65, 125-136, 1990.

Petrovský, E. and Kapička, A.: On determination of the Curie point from thermomagnetic curves, J. Geophys. Res., 111, B12S27, doi:10.1029/2006JB004507, 2006.

Pratesi, G., Cipriani, C., Guili, G., and Birch, W. D.: Santabarbaraite: a new amorphous phosphate mineral, Eur. J. Mineral., 15, 185-192, 2003.

Pratt, A. R.: Vivianite auto-oxidation, Phys. Chem. Minerals, 25, 24-27, 1997.

Rodgers, K. A.: Metavivianite and kerchenite: A review, Mineral. Mag., 50, 687-691, 1986.

Rodgers, K. A. and Henderson, G. S.: The thermochemistry of some iron phosphate minerals: vivianite, metavivianite, baracite, ludlamite and vivianite/metavivianite admixtures, Thermochim. Acta, 104, 1-12, 1986.
Rodgers, K. A., Kobe, H. W., and Childs, C. W.: Characterization of vivianite from Catavi, Llallagua Bolivia, Mineral. Petrol., 47, 193-208, 1993.

Roldán, R., Barrón, V., and Torrent, J.: Experimental alteration of vivianite to lepidocrocite in a calcareous medium, Clay Minerals, 37, 709-718, 2002.

Rosenquist, I. T.: Formation of vivianite in Holocene clay sediments, Lithos, 3, 327-334, 1970.

Sapota, T., Aldahan, A., and Al-Aasm, I. S.: Sedimentary facies and climate control on formation of vivianite and siderite microconcretions in sediments of Lake Baikal, Siberia, J. Paleolimnol., 36, 245-257, 2006.

Stamatakis, M. G. and Koukouzas, N. K.: The occurrence of phosphate minerals in lacustrine clayey diatomite deposits, Thessaly, Central, Greece, Mar. Geol., 139, 33-47, 2001.

Stoops, G.: SEM and light microscopic observations of minerals in bog-ores of the Belgian Campine, Geoderma, 30, 179-186, 1983.

Tanikawa, W., Mishima, T., Hirono, T., Soh, W., and Song, S. R.: High magnetic susceptibility produced by thermal decomposition of core samples from the Chelungpu fault in Taiwan, Earth Planet. Sci. Lett., 272, 372-381, 2008.

Thinnappan, V., Merrifield, C. M., Islam F. S., Polya, D. A., Wincott, P., and Wogelius, R. A.: A combined experimental study of vivianite and As (V) reactivity in the $\mathrm{pH}$ range 2-11, Appl. Geochem., 23, 3187-3204, 2008.

Wang, L., Pan, Y., Li, J., and Qin, H.: Magnetic properties related to thermal treatment of pyrite, Sci.in China. Ser. D: Earth Sci., 5, 1144-1153, 2008. 